\title{
Electricity Reform in China, India and Russia: The World Bank template and the politics of power
}

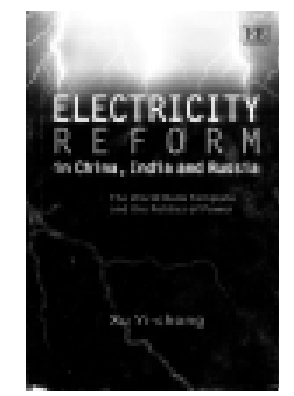

359 pp.

Reviewed by

K Ramanathan

Distinguished Fellow, TERI

International Journal of Regulation and Governance 5(1): 61-65

Since the early 1990s, power supply industry in many parts of the world has been going through a process of reforms and restructuring. The template of reforms had similar features like unbundling of vertically integrated utilities, change from public ownership to private ownership, evolution of a competitive power market, and establishment of independent regulatory bodies. It was expected that the reforms would lead to a vibrant power sector, protection of consumer interests, and minimize government spending in the sector. To what extent the different countries have been able to realize the goals of reforms and viability, applicability, and feasibility of market-led reforms in the developing countries, however, remains a hotly debated topic. The California crisis added more fuel to this debate. Nevertheless, the reform programme is spreading to all parts of the world, always with high expectations. A critical and comparative study of the process of reforms in countries with different political, legal, and economic systems should therefore be most welcome at this juncture. This book aims precisely at this and covers three countries, namely China, India, and Russia. The author has chosen the countries keeping in view the striking differences and similarities, in terms of development of electricity industry, legal and constitutional set-up, and economic development.

The book is structured into nine chapters. The introductory one dwells briefly on the reform template and experiences of a few of the developed countries. It then debates that the World 
Bank took the lead in developing a template for reforms following the experience in UK. The same was then applied in other developed and developing countries. According to the author, this was the resultant effort of 'the joint forces of the eager tutors of the Bank and international actors and the willing pupils of the local elite'. The observations are often quite sarcastic and this continues throughout the other chapters as well.

The second chapter examines the nature, organizational structure, and development of the electricity industry in different countries. Some of the inferences drawn are (a) ownership reform and restructuring need not take place simultaneously, it seldom did in the OECD (Organisation for Economic Cooperation and Development) countries, (b) to succeed, the reform model should fit to the local political and economic reality, and (c) competition is difficult when prices are inelastic or there are inadequacies in the generation, transmission, and distribution system. The author has tried to effectively highlight the risks involved in rushing through market reforms and to provide an eye-opener, especially for the developing countries with low levels of access to electricity.

The third chapter provides a brief survey of the political, legal, and economic systems of China, India, and Russia and an examination of their electricity industry. It also examines the interaction between political and economic institutions that govern the electricity industry in these countries. The author tries to conclude that there are 'some commonalties as well as many differences' between the three countries and hence a common reform template would not work. Some factual and editorial errors and omissions are however, seen in the text. A few of these in the Indian context relate to the growth in installed generation capacity in different plan periods (p. 66), structure of the industry (p. 73), absence of any mention to the 1998 Reform Act, the various state-level Acts and the Electricity Act, 2003 (p. 81), reference to the Indian Civil Service, etc. There is also an obvious mix-up of legends in Figures 3.1.

The fourth chapter examines how and why reforms were initiated in the three countries. The three triggering factors have been identified as external pressures from multilateral financial institutions (as the facilitating factor) and general economic reform in the country (as the contextual factor) and internal pressure due to immediate problems within the industry. Acknowledging that the factors varied significantly in the three 
countries, the author once again targets his criticism at the World Bank and the local 'technocrats and technopols' who try to copy the western models of reform.

The fifth chapter focuses on ownership reforms. It tracks the changing policies of the World Bank and its aggressive pursuit of corportatization and commercialization of state-owned enterprises by making it a conditionality for financial support. Experiences of the three countries are discussed at length, including the power politics, organizational conflicts, etc., which influenced reforms. In case of India, it is however restricted to Orissa. The lesson drawn towards the end namely, 'privatization is not a panacea for all ills' is a well-accepted fact.

The sixth chapter deals with the structural reforms of the electricity industry, namely the vertical and horizontal unbundling of the industry, functionally and organizationally. The author points out that by the end of the 1990s, the World Bank made structural reform a condition to developing and transition economies and provided 'solicited and unsolicited advice' to China, India, and Russia. Experiences of the three countries are detailed; in case of India it is again restricted to Orissa. There are a few verbatim repetitions within this chapter as well as with the chapter on ownership reform. Some of the statements also appear questionable. For example, it gives an impression that the international consultants deliberately projected a very low loss level (p. 211) in case of the OSEB (Orissa State Electricity Board) in India. Similarly, inadequacies in the transmission and distribution system have been quoted as the major reason for 'failure' in restructuring of the OSEB. The analysis also seems to extend to ownership reforms at places. The chapter again tries to conclude that 'public services can only be met with public obligations' and 'caution is needed in designing a specific model for reform in each country'.

The seventh chapter deals with regulatory reform in the three countries. The author has tried to conclude that 'it will take more than an independent regulatory agency to ensure fair competition, attract private investment, expand industry, or improve the economic performance of electricity enterprises'. The role of the government and the 'human and political realities' to be considered in regulation are reiterated in this context. The author quotes the experiences of China and Russia to make a point that without a formal and operational legal system, an independent regulatory agency cannot function effectively. The 
Indian experience is once again primarily restricted to Orissa. A reader familiar with the Indian power sector will also notice a few omissions and factual inaccuracies. For example, there is no reference to the state-level reform acts (eight, excluding Orissa) and the Central Act of 2003. Similarly, the statement that 'the ERC Act, 1998, was amended in 2001 to confirm the authority of ERCs to set electricity tariff' (p. 256) and the references to electricity law of 2000 (p. 229) are not factually correct. The author's conclusion that the issue of how to regulate the wires segments remains an unsolved technical question even in the developed countries (p. 277) is also debatable.

The eighth chapter on 'Reform complications' opens with the statement that 'no government can stand back from responsibility of electricity supply because in the extent of failure, electorates will hold them responsible, no matter whatever arm's length arrangements they may have put in place'. Hence, the author argues out that attention must be given to the political realities and unique problems each country faces in the process of reforms to avoid rigid solutions. The chapter focusses in particular, on the non-payment or non-cash payment problems in the three countries. It also deals with subsidies and cross subsidies. In case of China, the author identifies the relationship between the government, banks, and state-owned enterprises as one of the major constraints on growth and reform. In India, the non-payment issue has been rightly brought out as one between the central public sector undertakings, SEBs, and end-users. The problem in Russia relates to overdue accounts payable and non-cash settlement. The author has traced the steep growth in barter transactions, bulk of which relates to sales of intermediate goods such as fuel, building materials, and electricity. The liquidity and credit squeeze in economy and some interesting stories of barter deals prevalent in the country (for example, payment of wages in Vodka to fishermen) have been cited (p. 313). The author has also rightly acknowledged that the nonpayment problem in all the three countries is more than a sectoral issue and although there are some similarities, the causes are different and hence cannot be solved with a single package of market reform.

In the ninth and concluding chapter, the author has summarized his findings. He reiterates inter alia that (a) markets will not and cannot undertake the responsibility to ensure the public good and public service aspects; (b) a combination of private, 
local/state, joint-venture and public ownership can bring in competition and improved performance; (c) unbundling poses the risk of supply reliability; (d) guaranteeing universal access to electricity is imperative for human development and hence, pricing calls for delicate balancing of interests; and (e) one reform model does not fit all.

The book is an excellent addition to the literature on reforms in electricity. It has effectively articulated, albeit some repetitions, the risk of rushing through market reforms and adoption of a common template for reforms. How the local political and economic realities can impact reforms and the need for honouring the engineering and physical principles of the industry are also highlighted. It has also focused on the importance of the role of governments in reforming the sector. As regards India, it is, however, to be noted that the Orissa case cannot be taken as a representative of the country. The book should provide an interesting reading for policy-makers, reform consultants, and academics and help inculcate added pragmatism in their work on the electricity sector reforms. 